\title{
STRATEGI COPING STRESS MAHASISWA DALAM PENULISAN SKRIPSI
}

\author{
Made Saihu $^{1}$, M. Adib Abdushomad ${ }^{2}$, Encep Darisman ${ }^{3}$ \\ Institut PTIQ Jakarta ${ }^{1}$, Universitas Nahdlatul Ulama Indonesia ${ }^{2}$, IAIB Serang ${ }^{3}$ \\ Email: madesaihu@ptiq.ac.id ${ }^{1}$, abdushomad@gmail.com², \\ darismanencep@gmail.com ${ }^{3}$
}

\begin{abstract}
This study aims to determine the various problems and stress coping performed by students in preparing their thesis for STIT Al-Amin Kreo Tangerang students. There are 5 (five) informants involved in this study. The research approach used a qualitative approach with data collection techniques through observation, interviews, and FGD (focus group discussion). The results showed that the problem faced by students who were writing their thesis was between happiness and stress. On the one hand, they feel happy because they have reached the final peak of activities to obtain a bachelor's degree, will finish college, graduate and be able to find work after bachelor's degree. On the other hand, feeling stressed, such as feeling overwhelmed, confused, worried, afraid, insecure, anxious, feeling helpless and helpless or pessimistic, feeling guilty, feeling worried, nervous, feeling very tense, panic, restless, feeling chaotic, arises feelings of fear and anxiety, depressed, embarrassed and sometimes sad, feels tired, tired, upset, bored, bored and feels stuck in the mind. These feelings are caused by internal and external factors. In stress coping, students have strategies that focus on the emotional realm and do not use coping that is focused on problems. A strategy that is considered effective for students in writing a thesis so that the thesis does not become a scary thing.
\end{abstract}

Keywords: Coping Stress, Thesis, Student 


\begin{abstract}
ABSTRAK
Studi ini bertujuan untuk mengetahui berbagai problematika dan coping stres yang dilakukan mahasiswa dalam menyusun skripsi pada mahasiswa STIT Al-Amin Kreo Tangerang. Informan yang terlibat dalam penelitian ini berjumlah 5 (lima). Pendekatan penelitian menggunakan pendekatan kualitatif dengan teknik pengumpulan data melalui observasi, wawancara, dan FGD (focus group discussion). Hasil penelitian menunjukkan problematika yang dihadapi mahasiswa yang sedang menyusun skripsi adalah antara bahagia dengan stres. Di satu sisi mereka merasa bahagia karena sudah mencapai puncak akhir dari aktivitas untuk memperoleh gelar sarjana, akan selesai kuliah, wisuda dan dapat mencari pekerjaan setelah sarjana. Di sisi yang lain merasa stres, seperti merasa terbebani, bingung, khawatir, takut, tidak percaya diri, kecemasan, merasa tidak berdaya dan tidak berpotensi atau pesimis, adanya perasaan bersalah, terasa khawatir, gugup, perasaaan sangat menegangkan, panik, gelisah, merasa tidak karuan, timbul perasaan takut dan resah, tertekan, malu dan terkadang sedih, terasa penat, capek, galau, jenuh, bosan dan merasa pikiran jadi buntu. Perasaanperasaan tersebut disebabkan oleh faktor internal dan eksternal. Dalam coping stress mahasiswa strategi yang terfokus pada ranah emosional dan tidak banyak menggunakan coping yang terfokus pada masalah. Sebuah strategi yang dirasa ampuh untuk mahasiswa dalam menulis skripsi sehingga skripsi tidak menjadi sebuah hal yang menakutkan.
\end{abstract}

Kata Kunci: Coping Stress, Skripsi, Mahasiswa 


\section{PENDAHULUAN}

Skripsi merupakan tugas akhir mahasiswa di perguruan tinggi tidak saja mendatangkan kebahagiaan tetapi juga berdampak kepada psikologi. Banyak mahasiswa merasa terhantui dalam pengerjaannya sehinga memunculkan stress tersendiri dan memunculkan berbagai coping stress (F.J. Monks, 2001, p. 260). Umumnya mahasiswa yang sedang menyusun skripsi menunjukkan gejala stres, antara lain banyaknya keluhan, merasa kebingungan, mengaku sulit tidur, bahkan sering terlihat cemas (Aditama, 2017, pp. 39-62). Sebagian besar mahasiswa memiliki tingkat self-disclosure pada dalam berbagai kategori ketika menulis skripsi (Gamayanti, Mahardianisa, \& Syafei, 2018, pp. 172-179). Penulisan skripsi menuntut adanya kemandirian dalam mencari solusi terhadap masalahmasalah yang dihadapi baik yang disebabkan oleh aturan kampus juga disebabkan oleh karakteristik mahasiswa itu sendiri dan dosen pembimbing.

Studi hubungan antara penulisan skripsi dengan tingkat stress mahasiswa berkembang dari studi yang awal tentang adanya rasa gembira untuk segera menyelesaikan kuliah dan segera mendapat gelar sarjana, faktor-faktor yang melatarbelakangi keterlambatan, psikologis dan tingkat stress mahasiswa semester akhir, hingga studi tentang solusi membuat skripsi bagi mahasiswa. Pada awalnya, menulis skripsi merupakan mata kuliah akhir yang dinanti mahasiswa dengan alasan setelah menyelesaikan skripsi, wisuda, dan akan segera memperoleh gelar sarjana (Di, Bina, \& Polewali, 2017, p. 31). Studi mutakhir memperlihatkan bahwa adanya berbagai usaha coping stress untuk mengurangi tekanan psikologi dalam menulis (Andriyani, 2019, p. 37) Pada era modern dan postmodern pemahaman berbagai coping stress membawa angin segar bagi mahasiswa dalam menulis skripsi yang tadinya mendatangkan tekanan kejiwaan sekarang ini dinilai dapat menumbuhkan-kembangkan potensi, kecerdasan, dan kesadaran diri (Dela, 2019, pp. 90-94)

Tulisan ini didasarkan pada argumen bahwa menulis skripsi tidak hanya mendatangkan kebahagiaan bagi mahasiswa tingkat akhir, tetapi juga dapat mendatangkan persoalan baru bagi kejiwaan mahasiswa yang harus dihadapi. Coping stress sebagai sebuah aktivitas jiwa membutuhkan persyaratan dan fasilitas psikologi untuk dapat difungsikan secara maksimal. Pada saat yang sama coping stress memiliki kekuatan untuk memaksa kondisi kejiwaan dalam usaha menulis skripsi. Sebagai sebuah program psikologi, coping stress mengubah tradisi kecemasan dan kelelahan dalam menulis skripsi menjadi sebuah aktivitas yang dapat mengeluarkan seluruh potensi, kecerdasan, dan kesadaran diri. Dengan demikian, coping stress menuntut adanya berbagai pendekatan dan strategi dalam menyelesaikan penulisan skripsi.

Secara khusus, tulisan bertujuan menunjukkan pengalaman coping stress pada mahasiswa STIT Al-Amin Kreo Tangerang dalam menyelesaikan tugas akhir menulis skripsi. Selain mengidentifikasi tipe kesulitan yang dihadapi, tulisan ini juga menunjukkan strategi yang ditempuh dalam menghadapi permasalahan menulis skripsi. Aplikasi coping stress dalam menulis skripsi memberikan beban pada mahasiswa. Coping stress juga melahirkan pendekatan dan strategi baru dalam menyelesaikan tugas akhir kuliah. Dengan kata lain, tulisan ini menguji bahwa dibalik kenyamanan yang ditawarkan coping stress, membutuhkan strategi yang tidak mudah untuk ditempuh. 


\section{METODE PENELITIAN}

Metode yang digunakan dalam tulisan ini adalah kualitatif bertujuan untuk melihat fenomena strategi coping stress pada mahasiswa STIT Al-Amin Kreo Tangerang dalam aktivitas menulis skripsi yang difokuskan pada mahasiswa angkatan tahun 2016. Deskripsi dalam tulisan ini berupa kata-kata, lisan, kalimat, gambar dan bukan berupa angka dari informan (Moleong, 2016, p. 3), serta melihat fenomena yang ada di lokus penelitian (Knopp, 1998, p. 34). Penelitian dalam tulisan ini dilaksanakan mulai bulan juni sampa dengan september 2020.

Prosedur pengumpulan data dalam tulisan ini menggunakan metode observasi, yaitu mencatat secara sistematis terhadap gejala yang tampak objek dalam penelitian (Sugiyono, 2010, p. 310). Di sini peneliti terlibat langsung dengan kegiatan mahasiswa. Kedua dengan menggunakan metode wawancara mendalam dengan menggunakan alat perekam yang ada di Handphone. Informan dari pihak dosen berjumlah satu orang yang disajikan berdasarkan inisial nama, yaitu AA (I.1) Dipilihnya AA., sebagai informan dari pihak dosen berdasarkan pada jabatan dan kewenangannya. AA menjabat sebagai Wakil Ketua III sehingga memiliki data konseling seluruh mahasiswa. Sementara informan dari pihak mahasiswa berjumlah 3 orang, yaitu SM (I.3), KS (I.4) dan, AFN (I.5). NM, KS, AFN adalah mahasiswa yang saat penelitian ini dilaksanakan mereka sedang melakukan aktivitas penulisan skripsi. Tentu dari keduanya didapatkan data yang otoritatif terkait dengan tema yang dikaji.

Analisis data yang digunakan adalah metode deskriptif analitik, yaitu mendeskripsikan data yang dikumpulkan berupa kata-kata, gambar, dan bukan angka. Data yang berasal dari naskah, wawancara, cacatan lapangan, dokumen dan sebagainya, kemudian dideskripsikan sehingga dapat memberikan kejelasan terhadap kenyataan atau realitas. Dimulai dengan merumuskan dan menjelaskan masalah, sebelum terjun kelapangan dan berlangsung terus sampai penulisan hasil penelitian. Analisis dilakukan dalam tiga tahap, yaitu: 1) Reduksi data; 2) Penyajian data; dan 3) Penarikan kesimpulan.(Huberman, 1992, p. 321)Dari metode ini peneliti dapat menyajikan gambaran aktivitas atau strategi coping stress mahasiswa STIT Al-Amin Kreo Tangerang dalam Menulis Skripsi.

\section{HASIL DAN PEMBAHASAN \\ Beban dalam Menulis Skripsi Mahasiswa}

Dilihat dari artinya, kata coping berasal dari coping yang bermakna mengatasi atau penanggulangan (to cope with = mengatasi, menanggulangi). Secara sederhana coping sering dimaknai sebagai cara untuk memecahkan masalah. Namun coping lebih mengarahkan pada yang dilakukan untuk mengatasi tuntutan-tuntutan yang penuh tekanan.(Siswanto, 2007, p. 14) Coping juga bermakna upaya yang dilakukan seseorang untuk mengatasi, mengurangi, atau mentolerir ancaman yang menjadi beban perasaan dan dapat menimbulkan stress (Syamsu, 2005, p. 18). Atau dengan kata lain coping merupakan reaksi orang ketika menghadapi tekanan kejiwaan sebagai akibat dari beban yang terima.

Coping selalu diikuti dengan kata stress yang pada umumnya para ahli mendifinisakannya adanya peristiwa yang menekan sehingga seseorang dalam keadaan tidak berdaya akan menimbulkan dampak negatif, misalnya pusing, tekanan darah tinggi, mudah marah, sedih, sulit berkonsentrasi, nafsu makan bertambah, sulit tidur, ataupun merokok terus (Chandra, 2014, pp. 1-120). Stres juga dihubungkan dengan sisi stresor (sumber stres). Stres dalam hal ini digambarkan sebagai kekuatan yang menimbulkan tekanan-tekanan dalam diri, 
stres dalam pendekatan ini muncul jika tekanan yang dihadapi melebihi batas optimum (Fajar AS, 2016, p. 180). Dalam pendekatan interaksionis, stress didefinisikan dengan adanya transaksi antara tekanan dari luar dengan karakteristik individu, yang menentukan apakah tekanan tersebut menimbulkan stres atau tidak (Suharsono \& Anwar, 2020, p. 9). Dengan demikian coping stress adalah suatu usaha berbentuk kognitif maupun perilaku yang secara spesifik dilakukan untuk mengelola tuntutan-tuntutan yang menyebabkan stress.

Terkait dengan topik yang dibicarakan dalam tulisan ini, Abd Aziz, berpendapat bahwa skripsi merupakan tugas akhir mahasiswa yang harus diselesaikan sebagai mata kuliah terakhir (Wawancara dengan AA, 5 Juli 2020). Namun sebagaimana diakuinya banyak diantara mahasiswa memiliki kendala dalam penyelesaiannya baik itu disebabkan oleh kekurangan referensi, komunikasi dengan dosen pembimbing tidak lancar, sampai kepada masalah biaya. Seolah meng-iyakan argumen dari I.1, I.3, menyampaikan bahwa selama 4 (empat) bulan menulis skripsi, ia memiliki dengan dosen pembimbing sehingga sampai saat ini informan baru mulai melakukan pengambilan data. Proses yang panjang ini membuat informan sering merasa tertekan dan merasa stres. Informan biasanya mengerjakan skripsi di pondok pesantren dengan menggunakan komputer pribadi yang dimilikinya. Karena informan tidak lagi mengikuti kelas perkuliahan, maka informan lebih banyak berada di pondok pesantren dan hanya pergi ke kampus bila akan bimbingan atau pergi ke perpustakaan (wawancara dengan I.3, 6 Juli 2020).

Pada saat diwawancarai, informan (I.3) mengeluhkan sulitnya menemui dosen pembimbing yang hanya memberi waktu seminggu satu kali. Selain itu, informan juga mengemukakan kesulitan-kesulitan lain seperti susahnya mencari waktu untuk melakukan pengumpulan data di lokasi penelitian. Informan menjelaskan bahwa saat informan tertekan karena masalah skripsi, informan pergi ke mall untuk menenangkan diri. Setelah itu baru informan kembali mengerjakan skripsinya. Selain itu, informan juga berusaha mencari bantuan kepada temantemannya, terutama dalam mencari buku acuan sebagai referensi.

Informan berusaha untuk selalu menemui dosen pembimbing seminggu sekali untuk meminta petunjuk demi kemajuan perkembangan skripsinya. Namun demikian, infroman merasa arahan dan bimbingan yang diberikan oleh dosen kurang memadai karena biasanya informan hanya bertemu dengan pembimbing selama 5 sampai 10 menit. Waktu yang diberikan tersebut terasa kurang untuk memberi penjelasan, meskipun di lembar skripsi telah diberikan catatan-catatan khusus oleh pembimbing. Masalah lain yang dihadapi oleh informan adalah prosedur yang harus dilaluinya untuk melakukan pengambilan data. Informan harus mendatangi sebuah pondok pesantren dan mengatur waktu pengambilan data. Namun dalam proses ini, pondok pesantren hanya memberikan waktu yang terbatas, sedangkan data yang diperlukan oleh informan cukup banyak. Hal ini menjadikan proses pengambilan data berjalan sangat lambat dan kurang memadai. Terlebih lagi, ketika informan perlu menambah jumlah sampel tetapi pondok pesantren tidak mengizinkannya karena kedaan pandemi saat ini.

Informan mengalami dilema karena arahan dosen pembimbing mengharuskannya mengambil sampel lebih banyak sedangkan lokasi penelitian tidak mengizinkannya. Untuk mengatasi rasa stres yang dialaminya, informan berusaha menjelaskan pada dosen pembimbingnya tentang kesulitan mendapatkan sampel yang lebih besar. Informan berinisial SM berusia 25 tahun berasal 
Kabupaten Semarang. Sebagai anak petani dan anak ke 7 dari 8 bersaudara, informan bertekad untuk dapat menyelesaikan kuliahnya tepat waktu.

Dari awal wawancara sampai akhir wawancara dengan menggunakan hand phone, informan terlihat santai dan cukup tenang meskipun banyak mengeluhkan kelangsungan penyusunan skripsinya. Bahkan proses wawancara juga diselingi senda gurau karena informan memang dikenal suka bergurau. Informan terlihat agak sedih saat bercerita tentang harapan orang tuanya agar informan segera menyelesaikan kuliah.

Dari hasil wawancara dengan informan dapat diketahui bahwa usaha coping stress yang dilakukan oleh informan SM adalah sebagai berikut:

Pertama, Active coping, yaitu mengambil tindakan secara aktif untuk mengatasi stres. Tindakan mengatasi masalah yang dilakukan oleh subjek merupakan usaha untuk mencoba memperbaiki dampak yang bisa ditimbulkan atau untuk menghindari tekanan yang ada. Tindakan-tindakan tersebut berupa sikap menanyakan dan memperjelas penyebab stressor atau meninggalkan stressor (Michaels et al., 2019). Hal ini tampak dalam pernyataan subjek:

"browsing-browsing internet cari referensi, ke perpustakaan, lihat-lihat judul yang lain. Gitu-gitu aja. Kadang konsultasi juga ke dosen yang ngasi judul. ya paling cari-cari referensi dari internet. Aku ke UIN cari materi referensi juga. menanyakan lagi pada pembimbing maksudnya harus bagaimana, kadang kan tidak jelas memberi petunjuk, apalagi pembimbingnya kan ada 2 ya sering tidak klop."mengkonfirmasi ke pembimbing, sudah benar atau belum konsep yang dipakai. Kalau pakai instrumen ini gimana, boleh ngga, atau buat sendiri, ya hal-hal seperti itu lah harus disetujui dosen dulu. Baru berani mencari data"

Kedua, planning, yaitu memikirkan tentang cara mengatasi penyebab stress. subjek memikirkan bagaimana mengatasi stres yang dialaminya, bagaimana menentukan tindakan yang diambil serta bagaimana cara penanganan yang terbaik untuk memecahkan masalah (Hasanah, 2017, p. 139). Pernyataan subjek yang sesuai dengan hal-hal ini diantaranya:

"alternatif terakhir aku minta bantuan untuk olah datanya. Mending gitu lebih cepat daripada aku kesusahan. Paling tidak sedikit membantu aku ngga begitu memikirkan masalah olah datanya. Meskipun aku juga harus belajar. Sebelum bimbingan sudah aku siapin dulu yang aku tulis apa jadi ya nti kalo ditanya alasannya bisa jawab"

Ketiga, Restraint coping, yaitu menunggu saat yang tepat untuk bertindak. Subjek cenderung menahan diri untuk mengatasi tekanan. Subjek juga mempertimbangkan situasi dan kondisi stressor terlebih dahulu saat akan melakukan sesuatu. Sehingga seringkali subjek hanya akan menunggu saat yang dirasa tepat untuk melakukan tindakan (Esperanza \& Bulusan, 2020). Hal ini dinyatakan oleh subjek:

"apa ya.. Saat pusing ngerjaken skripsi, ya aku tinggal dulu... ngademken pikir. Kalo sudah adem, baru dikerjain lagi. Pelan-pelan lah"

Keempat, Positive reframing, yaitu mencoba menafsirkan suatu kondisi dengan lebih positif. Hal ini ditunjukkan oleh subjek dengan pernyataan:

"skripsi sulit ya wajar, kalau gampang ya SMA aja. Dijalani aja, nek sudah waktunya kan ya lulus. kalau pusing, ya banyak temannya. Skripsi memang harus pusing, kalau ngga pusing, ngga afdol?

Kelima, Mental disengagement adalah usaha untuk mengalihkan perhatiannya dari stressor. Usaha ini ditunjukkan oleh perilaku subjek yang 
melakukan kegiatan lain untuk menghindari penyebab stress yang dirasakannya. Hal ini dinyatakan subjek sebagai berikut:

"aku biasanya kalau lagi mumet ya, wudhu, solat, kadang dengerin musik sambil tidur-tiduran"

Informasi yang sama juga diperoleh dari informan kedua berinisial SK yang saat ini berusia 23 tahun, berasal dari Kabupaten Brebes. Informan adalah anak pertama, orang tuanya bekerja sebagai pedagang. Informan telah melakukan penulisan skripsi selama kurang lebih 4 bulan dan telah memasuki bagian terakhir dari penulisan. Informan tidak mengalami banyak kendala dalam penulisan skripsi yang membuatnya stres, kecuali dalam hal pengolahan data secara statistik. Selain itu, Informan mengalami hambatan di awal saat menyusun proposal. Berkali-kali informan harus mengganti topik dan judul penelitian sehingga membuat informan hampir menyerah. Setelah berkonsultasi dengan dosen pembimbing, akhirnya informan memilih salah satu topik penelitian yang berhubungan dengan dunia pendidikan.

Setelah seminar proposal, informan ditetapkan memiliki dua pembimbing yang menurut informan adalah dosen-dosen yang mudah ditemui dan baik. Informan dapat melakukan bimbingan di rumah maupun di kampus. Hal ini memudahkan informan untuk menyelesaikan skripsinya. Dalam satu minggu informan kadang bimbingan lebih dari satu kali, sehingga proses penulisan menjadi lebih cepat. Informan mengaku kesulitan mulai dirasakan setelah informan melakukan pengambilan data. Informan tidak paham statistik sehingga tidak tahu apa yang harus dilakukan dengan data tersebut. Informan sempat mundur beberapa minggu karena bingung. Sampai akhirnya Informan mendapatkan bantuan dari teman yang membantunya melakukan pengolahan data secara statistik (wawancara dengan SK, 10 Juli 2020).

Wawancara dengan informan SK dilakukan di lingkungan kampus, yaitu di perpustakaan pada sore hari setelah kegiatan perkuliahan sudah mulai sepi. Informan adalah salah satu teman satu angkatan. Karena telah mengenal informan dengan baik, maka wawancara dilakukan secara non formal dan cenderung santai. Informan dengan sukarela memberikan informasi secara jujur dan terbuka pada peneliti. Selama wawancara informan tidak menunjukkan wajah yang tertekan, bahkan terkesan sudah lega karena penulisan skripsinya hampir selesai. Selama wawancara informan banyak tertawa dan justru menyemangati peneliti untuk segera menyelesaikan skripsi.

Analisis data yang dapat diambil dari informan melalui:

Pertama, Active coping, yaitu informan dengan menceritakan masalah pada orang lain. Dengan cara ini informan juga mampu menenangkan emosi dalam diri sendiri dan berusaha tetap menjalani hidup seperti sebelum mengalami masalah dalam penyusunan skripsi. Hal ini dinyatakan informan dalam wawancara sebagai berikut:

"Cari-cari judul sendiri dulu lalu dikonsultasikan pada dosen. Cerita ke teman, seperti sama pacar gitu. Kadang ya minta bantuan ngetik".

Kedua, Supression of competing activities (penekanan pada aktivitas utama). Coping ini dilakukan dengan berusaha fokus pada masalah yang dialami, membatasi kegiatan yang bisa menimbulkan masalah baru, berusaha mendapatkan informasi yang berkaitan dengan masalah yang dialami. Informan menggunakan coping suppression of competing activities seperti diungkapkan dalam wawancara: 
"aku jarang main sama teman, ya ngga seperti dulu sebelum skripsi. Sekarang sih fokus dulu sama skripsinya. Kalau sudah selesai kan bisa jalan-jalan semaunya lebih banyak di perpus sekarang mencari materi, baca-baca referensi”.

Ketiga, Planning (perencanaan). Informan menggunakan coping planning dengan membuat rencana penanganan masalah penyusunan skripsi dan berusaha mempersiapkan dengan baik penulisan skripsinya. Hal ini diungkapkan informan dalam wawancara sebagai berikut:

Aku sudah buat rencana penulisannya, pokoknya setiap minggu harus ada kemajuan. Bab I sampai III kan sudah tinggal revisi dikit setelah seminar. Pengambilan data sebulan harus selesai trus buat analisa kira-kira ya 2 minggu. pokoknya setiap selesai menulis aku langsung bimbingan, telpon dulu bisa ketemu dimana, apa dikampus, apa di rumah. Setiap bimbingan aku catet apa yang disuruh nambahin biar ngga bolak-balik salah terus. Yang penting rajin bimbingan

Keempat, Use of emotional support. Informan juga mengatasi stres dengan mencari dukungan moral, simpati, emosional. Hal ini diungkapkan informan sebagai berikut:

"ya biasane kalau sudah agak malas, diingatkan sama orang tua.Terutama kalau ada kesulitan ya aku curhat sama orang tua aku".

Selanjutnya informasi yang penulis dapat dari informan berinisial AFN adalah mahasiswa perempuan berusia 28 tahun. Saat ini informan tinggal di daerah Tangerang. Informan sedang dalam menyusun analisa dan pembahasan untuk skripsinya. Informan berasal dari angkatan yang lebih tinggi dari informan dan sudah lebih dari 4 tahun kuliah di UIN. Informan berasal dari keluarga besar, dia adalah anak ke-1 dari dua bersaudara. Selain informan, ada pula saudaranya yang saat ini kuliah di UNJ di program studi yang berbeda. Orang tua informan adalah karyawan swasta. Untuk kepentingan penulisan skripsinya, orang tua informan membelikan laptop yang saat ini selalu dibawa oleh informan kemanapun dia pergi. Meskipun sudah tidak ada kegiatan kuliah, informan masih sering berada di kampus untuk mengerjakan skripsi sekaligus memanafatkan fasilitas wifi yang ada di lingkungan kampus. Menurut informan, informan mengalami banyak kendala dalam penulisan skripsinya sejak awal. Infoman menjelaskan bahwa dia sudah lebih dari 4 bln lebih mengerjakan skripsi, tetapi prosesnya sangat lambat sehingga sampai sekarang belum selesai. Di awal penulisan, informan sering berganti judul karena materi yang diperoleh kurang mendukung. Alasan lain informan berganti judul adalah karena tidak sesuai dengan keinginan dosen pembimbing. Informan memiliki dua orang pembimbing yang sulit ditemui karena sering bepergian ke luar kota. Selain itu, informan juga sulit untuk menentukan teori yang harus digunakan. Proses penyusunan instrumen penelitian juga sangat sulit menurut informan hingga informan menyerah dan tidak mengerjakan skripsinya selama beberapa bulan.

Informan kembali mengerjakan skripsinya setelah mendapatkan dukungan moral dari orang tua untuk berusaha lebih keras. Akhirnya, dengan bantuan dari saudara dan teman-teman dekatnya, informan termotivasi lagi untuk menyelesaikan penyusunan instrumen penelitian. Saat ini informan telah selesai melakukan pengambilan data dan sedang dalam proses pembuatan analisa dan pembahasan penelitian. Informan sudah merasa lebih bersemangat sekarang karena penyusunan skripsi sudah mulai berjalan lancar lagi (wawancara dengan AFN, 30 Juli 2020) Peneliti melakukan wawancara dengan subjek di rumahnya karena informan malu jika bertemu di kampus. Pada awal wawancara informan 
menunjukkan agak sedikit tertekan karena diingatkan kembali pada proses penyusunan skripsi yang cukup sulit. Informan bercerita dengan agak sedih karena banyak kesulitan yang dihadapinya di awal penyusunan skripsi yang telah berjalan lebih dari satu tahun.

Informan menunjukkan perasaan bersalah saat bercerita tentang kemundurannya dalam menyusun skripsi yaitu selama kurang lebih 2 bulan informan tidak melakukan apapun untuk menyelesaikan skripsinya. Informan juga terlihat murung ketika bercerita tentang harapan orang tuanya yang menginginkan informan cepat lulus. Semangat informan mulai muncul saat bercerita tentang kemajuan penulisan skripsinya saat ini yang telah memasuki analisa dan pembahasan

Penulis menganlisis coping stress dari informan melalui:

Pertama, Active Coping, yaitu menenangkan emosi dalam diri sendiri, berusaha tetap menyelesaikan skripsi meskipun banyak mengalami masalah dan tetap menjalankan aktivitasnya sehari-hari. Hal ini muncul dari pernyataan informan dalam wawancara:

"meskipun sulit, tapi tetap saya jalani. Mau tidak mau harus dikerjakan.Kasihan orang tua yang membayar kuliah. skripsi itu kan hanya sebagian kecil dari kegiatan sehari-hari, kalau tidak mengerjakan skripsi biasanya saya main dengan teman atau mencari hiburan di Semarang"

Kedua, Suppression of competing activities (penekanan pada aktivitas utama). Informan berusaha fokus pada masalah yang dialami dengan cara mengesampingkan masalah lain yang dapat membuat konsentrasinya buyar. Selain itu informan juga berbagi dengan orang tua serta saudaranya untuk mengurangi stres yang dirasakan. Hal ini diungkapkan subjek dalam pernyataan:

"saya sering ditelpon orang tua, ditanya, perkembangan skripsi saya. Saya curhat pada mama biasanya diberi nasehat. akhir-akhir ini saya sering ke perpus untuk menyusun pembahasan. Jarang pergi sekarang, soalnya mau ngejar ujian secepatnya ada adik juga yang sering bantu cari materi. Kadang menemani di kampus"

Ketiga, Planning (perencanaan). Jenis coping planning menekankan pada pembuatan rencana dan persiapan untuk menyelesaikan skripsi. Informan melakukan merencanakan apa yang akan dilakukannya untuk mengurangi stres yang dia alami dengan cara:

"rencananya saya akan bimbingan seminggu 2 kali, kalau tidak nanti tidak bisa mengejar ujian. saya sudah mempersiapkan semua materinya, buku-buku saya fotocopy bahan"

Keempat, Use of religion. Sikap individu untuk menyelesaikan masalah dengan keagamaan. Hal ini diungkapkan subjek dalam wawancara sebagai berikut:

"saya hanya bisa banyak berdoa, pasrah, Tuhan mau buat apa dalam hidup saya. kalau Tuhan izinkan, pasti saya segera lulus, tidak ada yang mustahil".

\section{Strategi Coping Stress Mahasiswa}

Coping stress merupakan bentuk tindakan atau usaha yang dilakukan individu sebagai reaksi dari situasi yang penuh tekanan baik berasal dari luar maupun dari dalam dirinya. Proses penyusunan skripsi yang panjang seringkali membuat mahasiswa mengalami tekanan. Oleh karena itu ketidakmampuan mengadaptasikan keinginan-keinginan dengan kenyataan yang ada, baik kenyataan yang ada di dalam maupun di luar diri, sehingga menimbulkan tekanan batin dan konflik. Active coping, planning dan suppression of competing activities 
digunakan sebagai alternatif mencari solusi mengatasi stres oleh semua subyek.Ini menunjukkan bahwa subjek menggunakan coping stress yang berfokus pada masalah yang dihadapi.

Pada permasalahan yang ada dalam penyusunan skripsi, misalnya saat mengalami kendala dalam menyusun Tinjauan Pustaka (BAB II), mahasiswa memilih melakkan active coping dengan mencari referensi di perpustakaan dan meminjam buku acuan. Ini menunjukkan adanya usaha dari subjek untuk mengurangi stres dengan cara menghadapi masalah daripada meninggalkannya. Mahasiswa mengatasi tekanan yang dirasakan dengan berkunjung ke perpustakaan untuk mencari referensi yang dapat digunakan dalam penelitiannya. Selain itu mahasiswa juga meminjam buku-buku acuan yang dapat dipergunakan untuk menyusun dasar teori .Demikian pula saat subjek mengalami masalah penyusunan instrumen penelitian, para subjek berusaha menyelesaikan masalah dengan merencanakan tindakan selanjutnya sebelum melakukan bimbingan dengan dosen.

Subjek penelitian ini juga menggunakan suppression of competing activities atau menekan kegiatan lain yang dapat menimbulkan stres. Ini berarti bahwa subjek lebih banyak menggunakan waktunya untuk menghadapi masalah dalam menyusun skripsi. Ini dilakukan untuk mengurangi potensi timbulnya tekanan karena ada kegiatan lain yang juga membawa dampak stres pada subjek. Umumnya subjek memusatkan perhatiannya pada masalah skripsi karena ada tuntutan untuk segera lulus dari orang tua. Hal ini menjadi faktor pendorong yang memotivasi subjek untuk menghilangkan tekanan dalam penyusunan skripsi. Jenis emotional focused coping yang digunakan oleh dua subjek adalah use of emotional support. Ini menunjukkan bahwa subjek membutuhkan dukungan sosial dari orang-orang terdekat mereka seperti keluarga dan pacar. Dukungan sosial sangat penting artinya bagi subjek, karena dapat memberikan motivasi dan dukungan bagi subjek dalam mengurangi tekanan yang dialaminya. Ada pula subjek yang menggunakan use of religion sebagai alternatif mengurangi tekanan. Subjek yang religius menggunakan agama sebagai salah satu usaha untuk mengurangi stres yang dialaminya dengan cara berdoa dan menyerahkan bebannya kepada Tuhan. Use of religion pada penelitian ini hanya digunakan oleh subyek perempuan. Ini menunjukkan bahwa subjek laki-laki lebih cenderung pada penggunaan problem focused coping.

\section{KESIMPULAN}

Problematika yang dihadapi mahasiswa yang sedang menyusun skripsi adalah antara bahagia dengan stress. Di satu sisi mereka merasa bahagia karena sudah mencapai puncak akhir dari aktivitas untuk memperoleh gelar sarjana, karena harapannya akan selesai kuliah dapat diwisuda dan dapat mencari pekerjaan setelah sarjana. Akan tetapi dibalik itu ada perasaan stres karena menganggap skripsi adalah sebuah beban berat selama kuliah. Menghadapi skripsi sebagai sebuah pengalaman baru yang membuat mereka bingung apa yang harus dilakukan. Timbul perasaan takut dan khawatir akan bermasalah dengan pembimbing dan takut tidak mampu melaksanakan penelitian tersebut karena keterbatasan pengetahuan dalam meneliti. Bentuk-bentuk stres yang dialami oleh para mahasiswa yang sedang menyusun skripsi pada umumnya adalah merasakan kecemasan, merasa tidak berdaya dan tidak berpotensi atau pesimis, adanya perasaan bersalah karena merasa telah mengecewakan dosen pembimbing ketika 
skripsinya tidak sesuai keinginan pembimbing, terasa khawatir, gugup dan perasaan sangat menegangkan, panik, gelisah, merasa tidak karuan, timbul perasaan takut dan resah, merasa tertekan, malu dan terkadang sedih. Ada di antara mereka yang mengatakan terasa penat, lelah, galau, jenuh, perasaan bosan dan merasa pikiran jadi buntu. Sehingga dapat disimpulkan ada faktor internal dan eksternal yang dialami mahasiswa dalam menulis skripsi. Sementara strategi coping stress yang dilakukan mahasiswa STIT Al-Amin adalah terfokus pada emosi (emotion focused coping) dan terfokus pada masalah (problem focused coping). Sebuah strategi coping yang bisa dijadikan rujukan bagi mahasiswa dalam menulis skripsi.

\section{DAFTAR PUSTAKA}

Aditama, D. (2017). Hubungan antara spiritualitas dan stres pada mahasiswa yang mengerjakan skripsi. Jurnal EL-Tarbawi, 10(2), 39-62.

Andriyani, J. (2019). Strategi Coping Stres Dalam Mengatasi Problema Psikologis. At-Taujih: Bimbingan Dan Konseling Islam, 2(2), 37. https://doi.org/10.22373/taujih.v2i2.6527

Chandra, J. (2014). Pengaruh Stres Kerja dan Kepuasan Kerja Terhadap Kinerja Karyawan Pada P.T. Lie Fung Surabaya. Jurnal Administrasi Bisnis, 1(2), $1-20$.

Dela, V. L. (2019). Strategi Coping Stress Pada Mahasiswa. Jurnal Bimbingan Konseling, 4(2), 90-94.

Di, S., Bina, S., \& Polewali, G. (2017). PENDAHULUAN Tertawa adalah kemampuan yang hanya dimiliki manusia yang merupakan ekspresi kebahagian dan bisa dilakukan tanpa syarat dan sama batuk dan flu kronis , gangguan syaraf, insomnia, gangguan pencernaan , alergi, bahkan kanker . Dalam terapi te. Bina Generasi: Jurnal Kesehatan, 9(1), 31. https://doi.org/https://doi.org/10.35907/bgjk.v9i1

Esperanza, E. T., \& Bulusan, F. (2020). Stressors and coping mechanisms of college scholarship grantees: A quantitative case study of an island higher education institution. Universal Journal of Educational Research, 8(5), 2156-2163. https://doi.org/10.13189/ujer.2020.080555

F.J. Monks, D. (2001). Psikologi Perkembangan Pengantar dalam Berbagai Bagiannya. Yogjakarta: Gadjah Mada University Press.

Fajar AS. (2016). Stress Oksidatif Dan Status Antioksidan Pada Aktivitas Fisik Maksimal. Jurnal Generasi Kampus, 9(2), 176-189.

Gamayanti, W., Mahardianisa, M., \& Syafei, I. (2018). Self Disclosure dan Tingkat Stres pada Mahasiswa yang sedang Mengerjakan Skripsi. Psympathic: Jurnal Ilmiah Psikologi, 5(1), 115-130. https://doi.org/10.15575/psy.v5i1.2282

Hasanah, U. (2017). Hubungan antara stres dengan strategi koping mahasiswa tahun pertama akademi keperawatan. Jurnal Wacana Kesehatan, 1(1), 138-145. Retrieved from https://garuda.ristekbrin.go.id/documents/detail/724051

Huberman, M. \&. (1992). Analisis Data Kualitatif. Jakarta: UI Press.

Knopp, R. B. B. and S. (1998). Qualitative Research for Education: An Introduction to Theory and Methods. Boston: Allyn and Bacon.

Michaels, E. K., Reeves, A. N., Thomas, M. D., Price, M. M., Hasson, R. E., Chae, D. H., \& Allen, A. M. (2019). Everyday racial discrimination and 
hypertension among midlife african american women: Disentangling the role of active coping dispositions versus active coping behaviors. International Journal of Environmental Research and Public Health, 16(23). https://doi.org/10.3390/ijerph16234759

Moleong, L. J. (2016). Metodologi Penelitian Kualitatif. Bandung: Remaja Rosdakarya.

Siswanto. (2007). Kesehatan Mental Konsep, Cakupan, dan Perkembangan. Yogjakarta: Andi Offset.

Sugiyono. (2010). Metode Penelitian Pendidikan: Pendekatan Kuantitatif, Kualitatif, dan $R \& D$ (11th ed.). Bandung: ALPABETA.

Suharsono, Y., \& Anwar, Z. (2020). Analisis Stres dan Penyesuaian Diri pada Mahasiswa. Cognicia, 8(1), 1-12. Retrieved from http://ejournal.umm.ac.id/index.php/cognicia/article/view/11527

Syamsu, Y. (2005). Mental Hygiene Perkembangan Kesehatan Mental dalam Kajian Psikologi dan Agama. Bandung: Pustaka Bani Quraisy 